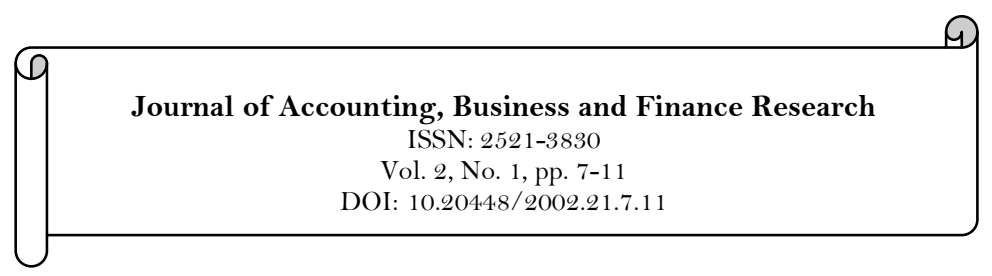

\title{
Empirical Relationship between Operational Efficiency and Profitability (Evidence from Pakistan Exploration Sector)
}

\author{
Amna Muhammad Shafi Azad ${ }^{1}$ \\ Ali Raza ${ }^{2}$ \\ Syed Shahid Zaheer Zaidi ${ }^{3}$
}

${ }^{1,2}$ MPhil Scholar, Department of Commerce, University of Karachi.

${ }^{3}$ Assistant Professor, Department of Public Administration, University of Karachi.

\begin{tabular}{l|l}
\multicolumn{1}{c}{ Abstract } & \\
This study is a part of our course work. In this study the operational & Keywords: \\
efficiency of firms is checked against profitability. For the purpose of & $\begin{array}{l}\text { Total assets turnover } \\
\text { research oil and gas sector of Pakistan stock exchange is selected. Six }\end{array}$ \\
years data from $2010-2015$ is collected through financial reports of & $\begin{array}{l}\text { Debtors turnover } \\
\text { Current ratio } \\
\text { companies. Since efficiency can be measured through several financial }\end{array}$ \\
ratios. In this article total asset turnover, fixed assets turnover, & \\
debtors turnover are used as explanatory variables and current ratio & JEL Classification: \\
and quick ratio as control variables. The profitability of firms is & G-30, G-31, G-32, L-25. \\
measured through return on equity. Ordinary least square, & Licensed: \\
correlation matrix and descriptive statistics are used to describe the & This work is licensed under a \\
findings of the study and features of the data. The results of the & Creative Commons Attribution \\
study show that the total assets turnover, debtors turnover and quick & 4.0 License. \\
ratio have strong negative impacts on the profitability measured by & Publisher: \\
ROE, of firms. The current ratio and fixed asset turnover have & Scientific Publishing Institute \\
positive impacts on the return on equity. The results of the study & \\
support the hypothesis that efficiency as measured by (total assets & \\
turnover, debtors' turnover, quick ratio current ratio and fixed asset & \\
turnover) has impacts on the profitability of firms. &
\end{tabular}

\section{Introduction}

The study has been performed to know the empirical relationship between operational efficiency and profitability. Efficiency no doubt impacts on the performance of firms. One of the most important goals of company management is to maximize its effectiveness current and future financial and business performance as they affect market price per share and shareholder wealth (Gill, Singh, Mathur, \& Mand, 2014). Different ratios like asset turnover ratio, inventory turnover ratio, fixed asset turnover ratio, accounts receivable turnover ratio and working capital turnover ratio are used as proxies of operational efficiency. How far all these ratios impact the performance of firms is defined as efficiency. In this study, total asset turnover, fixed asset turnover and accounts receivable turnover are used as efficiency ratios and current ratio and quick ratio as control variables. Profitability of firms is measured through ROE. The concept of operating efficiency has drawn attention as competition intensifies the evolution of processes and new technologies. Whenever there is more uncertainty, businesses may decide to diversify their portfolios and / or improve their investment portfolios to reduce risk. Due to the extremely changes in business environment, enterprises are facing severe competition, which is why one good business performance is crucial to a successful business (Goel, 2012). Increasing operational efficiency directly affects the organization's profitability efficient businesses are more cost-effective. Any aspect of operational efficiency business types are crucial and must be earned by management for consideration healthy and sustainable financial performance (Sufian, 2007).

Efficient firms perform better than inefficient firms in every sense. Efficiency not only bless firm with quality production but also cost savings. Through all ratios of efficiency we find that how much we earn for per dollar of total assets turnover, fixed assets turnover, accounts receivable turnover and working capital turnover.

Organizational efficiency depends on factors Skilled workers, appropriate technological advances, appropriate purchases carryout, scale of enterprise return, supply chain control and more. Relatively speaking, 
more efficient enterprises tend to maintain a higher level of stability production and operating performance compared with other peers (Mills \& Schumann, 1985).

Financial performance measures how companies use their resources (in the main business to generate returns). Financial performance has an impact on the company's health and decides to keep continue or to exist. Daily better marginal performance improves the effectiveness and efficiency of company management resources. A good calculation and hiring day to day expense on management, these are expected to have a positive impact on the formation of corporate wealth. This in turn helps to profit, thus contributing to economic growth big. In order to improve overall performance, companies should minimize the risk factor to control uncertainty; this is the premise of enterprises to understand the business determinants of working capital and appropriate intensity (Naser \& Mokhtar, 2004).

The efficiency scores obtained by the organization can be used to set the operation strategy that enables businesses to achieve their business goals and objectives by strengthening them allocate available resources to maximize your company's output (Reid \& Sanders, 2007). If businesses are more efficient, they may expect increase productivity and increase profits. Therefore, consumers can expect better, more fair prices, good service, better safety and reliability (Berger, Hunter, \& Timme, 1993). Cho and Pucik (2005) studied the quality, innovation, growth, profitability and the company's market value. The results of the structural equation model show quality have different effects on profitability and growth. Quality has direct impact profitability, its impact on growth, is adjusted by innovation.

The oil and gas exploration sector of Karachi stock exchange is selected for the purpose of research. It is one of the most profitable sectors of Pakistan Stock Exchange. There are four companies in this sector. These are Pakistan Petroleum Limited, Oil and Gas Development Company limited, Pakistan Oilfields Limited and Mari Petroleum Company limited. All are included in the research. Six years data of these companies from 2010 to 2015 is collected.

\section{Literature Review}

A brief review of the previous literature is presented here.

The study conducted by Gill et al. (2014) on the Indian manufacturing firms to know the impact of operational efficiency on the future performance. They searched the factors which contribute to the future performance of Bombay stock exchange from 2008-2012. How far a firms operating cash flow, cash conversion cycle, asset turnover ratio, firm size and operating risk impact the future performance of firm is defined as efficiency of firms. The study based on the theory that current operational efficiency measured by cash conversion cycle, asset turnover, operating expenses and operating cash flow impacts the future performance of firms positively or negatively. The weighted least square method was used for two industries i.e. consumer products manufacturing and industrial products manufacturing with cross section weights to reduce heteroskedasticity. The findings of the study suggest that cash conversion cycle and operating expenses ratio negatively impact future performance. Asset turnover and operating cash flows have positive impact on future performance measured by share price.

Another study conducted by Baik, Chae, Choi, and Farber (2013) using frontier analyses approach to know the impact of operational efficiency on the profitability of firms. They prefer frontier analyses because financial ratios are less precise than measures derived from frontier analyses. A significant advantage is that the frontier analyses implicitly allows for differential weighting among inputs. Two measures of frontier analyses operational efficiency derived from Data Envelopment Analysis (DEA) and Stochastic Frontier Analysis (SFA) are used. Sales revenue is used as input variable and cost of goods sold, general and admin costs and property plant and equipment are used as input variables. The findings of study suggest that efficiency measured by frontier analyses have positive impact on current and future profitability.

A study on the services sector of Jordan, Amman has been conducted by Warrad and Al Omari (2015) in the similar area. They concluded that efficiency measured by asset turnover; fixed asset turnover and working capital turnover have no significant impact on the profitability measured by ROA and ROE.

An Italian researcher (Santosuosso, 2014) worked in the same area on the sample of 215 non financial firms listed on the Italian stock exchange from 2004-2013. The total asset turnover, receivable turnover, inventory turnover and revenue per employee are considered as independent variables. The EBITDA to total assets, ROA and ROE are taken as dependent variables as proxies of profitability. Santosuosso also searched about the association b/w efficiency and stock market value using market to book value, price to earnings ratio and market to sale ratio. The association b/w efficiency and cash flow also calculated by cash flow to total asset ratio, cash flow to debt ratio and cash flow to accounts payable ratio. The result suggests the most significant association $\mathrm{b} / \mathrm{w}$ proxies of efficiency and measure of profitability i.e. EBITDA to total assets. The correlation is weak for other proxies of efficiency i.e. ROA and ROE. It was also found that if account receivable turnover increases the firm capability to pay off debt increases. Further turnover ratios and stock market value have not significant relationship.

A study of U.S retail industry regarding the stability of the financial ratios specifically the trend of those ratios which measure the efficiency and profitability. The researcher concluded that a higher cash conversion cycle leads to higher profitability and a lower cash conversion cycle leads to lower profitability. 
Another study is regarding the impact of efficiency due to the increase legislations of European Union Directives and Japanese home electrical appliances recycling law on the profit seeking automobile manufacturers in an oligopoly market. The study concluded that the regulations driven manufacturers towards the cost saving engines and fuel efficiency and thereby increased profit.

Another study was conducted in Ghana to know the efficiency and profitability relationship. The profit of listed banks was examined against liquidity, credit risk, leverage, productivity and size. It is concluded that $60.74 \%$ of the changes in profit is due to the discussed independent variables.

One of the study was conducted to know that how profit planning efficiency impacts goal achievement and firm success. Data of the research was collected from 967 canned food businesses in Thailand. According to this study profit planning efficiency significantly impacts the goal achievement and success of firm.

\section{Research Methodology}

The study is based on secondary data. Six years data from 2010 to 2015 is taken from the annual reports of the four companies of oil and gas exploration sector. Due to small number of companies the whole industry is included in the experiment. Sampling technique is not applied in the study. The theoretical foundation of the study is based on the assumption that efficiency impacts the profitability of firms in the future either positively or negatively.

The variables are selected as proxies of efficiency and explanatory are total asset turnover, fixed asset turnover and accounts receivable turnover. Control variables are current ratio and quick ratio.

The profitability of firms is measured through Return on Equity (ROE). Since ROE is a dependent variable which will be explained by five explanatory variables.

Hypothesis design;

On the basis of theoretical foundations following hypotheses are made to check;

1- Change in the total assets turnover ratio of oil and gas exploration sector of Pakistan stock exchange changes the return on equity from 2010 to 2015.

2- Change in the fixed assets turnover ratio of oil and gas exploration sector of Pakistan stock exchange changes the return on equity from 2010 to 2015.

3- Change in the accounts receivable turnover ratio of oil and gas exploration sector of Pakistan stock exchange changes the return on equity from 2010 to 2015.

4- Change in the current ratio and quick ratio of oil and gas exploration sector of Pakistan stock exchange changes the return on equity from 2010 to 2015.

The four hypotheses are examined in the light of data provided for research purpose. The Ordinary Least Square (OLS) method is used to find results.

\section{Findings}

Correlation Matrix

\begin{tabular}{|c|c|c|c|c|c|c|}
\hline & $\begin{array}{l}\text { Return } \\
\text { on } \\
\text { equity }\end{array}$ & $\begin{array}{l}\text { Total asset } \\
\text { turnover }\end{array}$ & $\begin{array}{l}\text { Fixed asset } \\
\text { turnover }\end{array}$ & Quick ratio & $\begin{array}{l}\text { Current } \\
\text { ratio }\end{array}$ & $\begin{array}{l}\text { Debt turnover } \\
\text { in times }\end{array}$ \\
\hline $\begin{array}{ll}\text { Return } & \text { on } \\
\text { equity } & \end{array}$ & 1 & -0.359739 & -0.283088 & 0.353938 & 0.382981 & -0.96223 \\
\hline $\begin{array}{l}\text { Total asset } \\
\text { turnover }\end{array}$ & & 1 & 0.945797 & -0.552924 & -0.600934 & -0.049995 \\
\hline $\begin{array}{l}\text { Fixed asset } \\
\text { turnover }\end{array}$ & & & 1 & -0.517144 & -0.575926 & -0.154149 \\
\hline Quick ratio & & & & 1 & 0.989951 & -0.398742 \\
\hline Current ratio & & & & & 1 & -0.291719 \\
\hline $\begin{array}{l}\text { Debt } \\
\text { turnover in } \\
\text { times }\end{array}$ & & & & & & 1 \\
\hline
\end{tabular}


Descriptive Statistics

\begin{tabular}{l|l|l|l|l|l}
\hline & $\begin{array}{l}\text { Total asset } \\
\text { turnover }\end{array}$ & Quick ratio & Current ratio & $\begin{array}{l}\text { Fixed asset } \\
\text { turnover }\end{array}$ & $\begin{array}{l}\text { Return } \\
\text { equity }\end{array}$ \\
\hline Mean & 0.779583 & 2.712083 & 2.995833 & 2.027917 & 28.9 \\
\hline Median & 0.63 & 2.635 & 3.035 & 1.585 & 30.5 \\
\hline Maximum & 1.85 & 6.26 & 6.87 & 5.22 & 49.15 \\
\hline Minimum & 0.4 & 1.02 & 1.06 & 1.07 & 9.72 \\
\hline $\begin{array}{l}\text { Standard } \\
\text { deviation }\end{array}$ & 0.383638 & 1.43852 & 1.545785 & 1.159606 & 9.625415 \\
\hline Skewness & 1.375338 & 1.049168 & 0.945983 & 1.528554 & -0.119889 \\
\hline Kurtosis & 3.760257 & 3.733861 & 3.757592 & 4.077444 & 2.62384 \\
\hline Jarque bera & 8.144 & 4.941 & 4.153 & 10.506 & 0.198 \\
\hline Probability & 0.017041 & 0.084519 & 0.125338 & 0.00523 & 0.905295 \\
\hline Sum & 18.71 & 65.09 & 71.9 & 48.67 & 693.6 \\
\hline $\begin{array}{l}\text { Sum square } \\
\text { deviation }\end{array}$ & 3.385 & 47.595 & 54.957 & 30.928 & 2130.918 \\
\hline $\begin{array}{l}\text { Observations } \\
\text { Ordinary Least Square Method. }\end{array}$ & & & & 24 \\
\hline
\end{tabular}

Ordinary Least Square Method.

Dependent Variable; Return on Equity

\begin{tabular}{l|l|l|l|l}
\hline Variable & Coefficient & Std.error & t-statistic & Probability \\
\hline $\mathrm{C}$ & 32.416 & 12.527 & 2.588 & 0.0186 \\
\hline $\begin{array}{l}\text { Total asset } \\
\text { turnover }\end{array}$ & -17.724 & 16.337 & -1.085 & 0.292 \\
\hline $\begin{array}{l}\text { Fixed asset } \\
\text { turnover }\end{array}$ & 5.338 & 5.537 & 0.964 & 0.348 \\
\hline Debtors turnover & -1.449 & 1.667 & -0.869 & 0.396 \\
\hline Current ratio & 21.450 & 15.309 & 1.401 & 0.178 \\
\hline Quick ratio & 21.693 & 16.799 & -1.291 & 0.213 \\
\hline R-squared & 0.274737 & Mean dependent variable & 28.9 \\
\hline Adjusted r-squared & 0.073276 & S.D. dependent variable & 9.625 \\
\hline S.E of regression & 9.266 & Akaike info criterion & 7.503 \\
\hline Sum squared resid & 1545.475 & Schwarz criterion & 7.797 \\
\hline Log likelihood & -84.035 & Hannan-Quin criterion & 7.581 \\
\hline F-statistic f- & 0.284 & Durbin-watson stat & 1.649 \\
\hline $\begin{array}{l}\text { Probability } \\
\text { statistics }\end{array}$ & \multicolumn{3}{l}{} \\
\hline
\end{tabular}

Above are the findings of study in the correlation matrix, descriptive statistics and ordinary least squares. Findings of the study are discussed below

\section{Analysis}

The correlation matrix shows that there is no significant relationship between return on equity and efficiency ratios of the oil and gas exploration companies. Turnover ratios show weak negative relationship with return on equity.

The mean median and maximum minimum values are given in the descriptive statistics. Standard deviations are not too high. The skewness of total asset turnover, fixed asset turnover and quick ratio shows that distributions are highly skewed. However in the return on equity and current ratio the distributions are moderately skewed. The kurtosis of return on equity shows that distribution is platykurtic. The kurtosis of other variables shows that distributions are leptokurtic.

An analysis of ordinary least square tells a different picture.

The coefficients of total assets turnover, quick ratio and debtor turnover ratios show that there is strong negative impact of these variables on ROE. The coefficients of fixed asset turnover and current ratio are positive, showing a positive impact on ROE. The probabilities of t-statistics are also significant thus accept the null hypothesis of the study.

The R-Square value suggests that the model needs to increase variables so that results may better elaborate the relationship. The p-value of F-statistics is also significant and supports the null hypothesis that efficiency impacts profitability of firms. 


\section{Conclusion and Recommendations}

In this study the empirical relationship of efficiency and profitability is examined. In this regard the six year data of oil and gas exploration sector is collected from annual reports. The results of the study show that the total assets turnover, debtor's turnover and quick ratio have strong negative impacts on the profitability measured by ROE, of firms. The current ratio and fixed asset turnover have positive impacts on the return on equity. The results of the study support the hypothesis that efficiency as measured by (total assets turnover, debtor's turnover, quick ratio current ratio and fixed asset turnover) has impacts on the profitability of firms.

We have limited time, resources and data regarding the study. It is recommended therefore that to have a better picture more data is needed. Increased observations and resources can further generalize the results.

\section{References}

Baik, B., Chae, J., Choi, S., \& Farber, D. B. (2013). Changes in operational efficiency and firm performance: A frontier analysis approach. Contemporary Accounting Research, 30(3), 996-1026.

Berger, A. N., Hunter, W. C., \& Timme, S. G. (1993). The efficiency of financial institutions: A review and preview of research past, present and future. Journal of Banking \& Finance, 17(2-3), 221-249.

Cho, H. J., \& Pucik, V. (2005). Relationship between innovativeness, quality, growth, profitability, and market value. Strategic Management Journal, 26(6), 555-575.

Gill, A., Singh, M., Mathur, N., \& Mand, H. S. (2014). The impact of operational efficiency on the future performance of Indian manufacturing firms. International Journal of Economics and Finance, 6(10), 259-269.

Goel, S. (2012). Link between operational efficiency and solvency: The case of food processing industry in India.

Mills, D. E., \& Schumann, L. (1985). Industry structure with fluctuating demand. The American Economic Review, 75(4), 758-767.

Naser, K., \& Mokhtar, M. (2004). Determinants of corporate performance of Malaysian companies. Paper presented at the Fourth Asia Pacific Interdisciplinary Research in Accounting Conference, Singapore.

Reid, D., \& Sanders, R. (2007). Operations strategy and competitiveness. Operations Management Journal, 34(3), 43-55.

Santosuosso, P. (2014). Do efficiency ratios help investors to explore firm performances? Evidence from Italian listed firms. International Business Research, 7(12), 111.

Sufian, F. (2007). The efficiency of Islamic banking industry: A non-parametric analysis with non-discretionary input variable. Islamic Economic Studies, 14(1-2), 53-78.

Warrad, L., \& Al Omari, R. (2015). The impact of turnover ratios on Jordanian services sectors' performance. Journal of Modern Accounting and Auditing, 11(2), 77-85. 